\title{
POST-FERTILIZATION MATERNAL EFFECTS ON SPERM DIMENSIONS OF INBRED MOUSE STRAINS
}

\author{
K. P. PANT AND R. A. BEATTY \\ Institute of Animal Genetics, West Mains Road, Edinburgh EH9 $3 \mathcal{J N}$
}

(Received 27th November 1972)

\begin{abstract}
Summary. Transplantation of blastocysts from one inbred strain to another and consequent pre- and postnatal development with a different strain as mother has no apparent effect on sperm dimensions.
\end{abstract}

In experiments where mouse strains have been crossed with a view to studying the sperm dimensions of the hybrids, significant male and female parent effects have been observed (Beatty, 1969; Pant, 1972), and it seems that the effect of male and female parents is unequal (Beatty, 1972). Sharma (1960) carried out one-way crosses between several inbred strains of mice and some of the crosses resembled the maternal strain very closely in sperm dimensions. Illisson (1969) demonstrated a significant maternal effect on the head shapes of spermatozoa and suggested that such an effect might be due to a permanent influence on the undifferentiated germ cells or the Sertoli cells of the embryos. Beatty (1969) has discussed several other possible sources that may be responsible for differential male and female parent effects.

The present experiment was planned to study the possible effect resulting from the development of an embryo in the uterus and the consequent postnatal maternal effects on the sperm dimensions of the progeny. The other possible sources of maternal effects, such as those due to genes located on the $\mathrm{X}$ chromosome or due to factors being carried through the cytoplasm of the egg (Beatty, 1969), were therefore excluded from the 'maternal effect' that was being studied.

For the experiment, two inbred strains of mice, V and JBT, were available. Their sperm dimensions were known from a diallele cross of these two and two other strains (Pant, 1972, a brief report).

There were four groups of mice (Table 2) that are referred to as 'cells' in the following description. The two purebreds formed two of the 'cells'. The third 'cell' contained mice that were taken out of the $\mathrm{V}$ females at the blastula stage and transferred into the uteri of JBT females. Similarly, JBT embryos transferred to $\mathrm{V}$ females formed the fourth 'cell'. The technique of egg transfer has been described by McLaren \& Michie (1956) and Bowman \& McLaren (1970).

The male progeny were weaned 21 days after birth. In each 'cell', one male was randomly selected. This was thought to be an adequate sampling, because it is known that variation in sperm dimensions between males within inbred strains is virtually zero (Beatty \& Sharma, 1960; Beatty, 1970). The four males from the four 'cells' were killed in a random order for making sperm preparations. Their age at the time of killing varied between 81 and 88 days, and no 
effect of such a small age variation on sperm dimensions is anticipated (Beatty $\&$ Mukherjee, 1963). From each male, five nigrosin-eosin slides were made by the method of Hancock (1951) and mounted in DePeX. The slides were coded before examination. In each slide, ten spermatozoa were randomly selected and outline drawings of their heads and mid-pieces were made on sheets of paper, using a separate sheet for each spermatozoon, under a projection microscope (Woolley \& Beatty, 1967) at a linear magnification of $\times 6144$. The characteristics measured were head breadth, head area in optical projection and mid-piece length. The whole technique has been described by Beatty \& Sharma (1960).

In the statistical analysis, the variation between the four 'cell' means (on 3 d.f.) was divided into two main factors: (i) between the two genotypes, and (ii)

Table 1. Analysis of variance of sperm dimensions of $\mathrm{V}$ and JBT strains of mice, in $\mu \mathrm{m}$ units on a one 'cell' basis

\begin{tabular}{|c|c|c|c|c|}
\hline \multirow{2}{*}{ Source } & \multirow{2}{*}{ d.f. } & \multicolumn{3}{|c|}{ Mean squares } \\
\hline & & Head breadth & Head area & Mid-piece length \\
\hline $\begin{array}{l}\text { Transplantation plus host mother } \\
\text { Genotypes } \\
\text { Transplantation } \times \text { Genotypes } \\
\text { Preparations within cells } \\
\text { Spermatozoa within preparations }\end{array}$ & $\begin{array}{r}1 \\
1 \\
1 \\
16 \\
180\end{array}$ & $\begin{array}{l}0.0007039 \\
0.0008488 \\
0.0000045 \\
0.0004951 \\
0.0005083\end{array}$ & $\begin{array}{l}0.0667 \\
1.5935^{*} \\
0.0036 \\
0.0433 \\
0.0448\end{array}$ & $\begin{array}{l}0.01483 \\
1.02851^{*} \\
0.00013 \\
0.00530 \\
0.00329\end{array}$ \\
\hline
\end{tabular}

$* P<0.005$.

Table 2. Mean sperm dimensions of JBT and $\mathrm{V}$ males born without transplantation (native) and after transplantation to the other strain female

\begin{tabular}{|c|c|c|c|c|}
\hline $\begin{array}{l}\text { Dimensions } \\
( \pm S . E .)\end{array}$ & $\begin{array}{c}\text { Genotype } \\
\text { of } \\
\text { males }\end{array}$ & Native & Transplanted & $\begin{array}{c}\text { Overall } \\
\text { genotype } \\
\text { means }\end{array}$ \\
\hline $\begin{array}{l}\text { Head breadth } \\
(\mu \mathrm{m}) \pm 0.022\end{array}$ & $\underset{V}{J B T}$ & $\begin{array}{l}3 \cdot 681 \\
3 \cdot 708\end{array}$ & $\begin{array}{l}3.705 \\
3.736\end{array}$ & $\begin{array}{l}3 \cdot 693 \\
3 \cdot 722\end{array}$ \\
\hline $\begin{array}{l}\text { Head area } \\
\left(\mu \mathrm{m}^{2}\right) \pm 0.208\end{array}$ & $\underset{V}{J B T}$ & $\begin{array}{l}25 \cdot 581 \\
24 \cdot 378\end{array}$ & $\begin{array}{l}25 \cdot 899 \\
24.577\end{array}$ & $\begin{array}{l}25 \cdot 740 \\
24 \cdot 478\end{array}$ \\
\hline $\begin{array}{l}\text { Mid-piece length } \\
(\mu \mathrm{m}) \pm 0.073\end{array}$ & $\underset{V}{\text { JBT }}$ & $\begin{array}{l}21 \cdot 610 \\
22 \cdot 613\end{array}$ & $\begin{array}{l}21 \cdot 721 \\
22 \cdot 746\end{array}$ & $\begin{array}{l}21 \cdot 666 \\
22 \cdot 680\end{array}$ \\
\hline
\end{tabular}

between native and transplanted males. The remaining portion was termed a genotype : transplantation interaction (on 1 d.f.). Within 'cells', the variation was partitioned hierarchically as follows: preparations within 'cells', $\mathrm{P}(\mathrm{C})$; spermatozoa within preparations, $S(P)$. The item $P(C)$ was used as error to test the main effects between the 'cells' and itself was tested against $S(P)$. Thus, this analysis combines the effects of transplantation as a technique and posttransplantation maternal effects as one source of variation. The results of the analysis are presented in Table 1, and the 'cell' means are presented in Table 2.

It is clear from the analysis that there is no effect of transplantation and consequent development of the males on the sperm dimensions. It is unlikely, 
therefore, that the maternal effects that have been observed in previous studies are due mainly to the post-fertilization maternal environment. The other possibilities, which could not be isolated in the present experiment, are maternal cytoplasmic effect and an X-chromosome effect. It is possible that some genes located on the $\mathrm{X}$ chromosome may affect sperm dimensions. Small sampling in this experiment prohibits a serious consideration of these observations, especially since the variation in head breadth between the two genotypes was so small (the two strains did not differ in their head breadth, though the sperm heads of the $\mathrm{V}$ strain appeared to be shorter and broader in shape than those of the JBT). It seems from some of our unpublished work that the head breadth is also likely to be influenced by a combination of maternal and X-chromosome effects. However, it is certain that non-chromosomal maternal effects are not of any great importance. It seems worthwhile to attempt isolation of non-chromosomal maternal effects in a separate study, using those strains that differ widely in their sperm head breadth and show significant reciprocal differences in their $F_{1}$ s.

One of us (K.P.P.) is grateful to the Association of Commonwealth Universities in the United Kingdom and the Ford Foundation for financial assistance. The egg transfers were kindly performed by Mr P. S. Burgoyne.

\section{REFERENCES}

BEATTY, R. A. (1969) A genetic study of spermatozoan dimensions in mice selected for body weight. Indian $\mathcal{F}$. Hered. 1, 9.

BeAtTy, R. A. (1970) The genetics of the mammalian gamete. Biol. Rev. 45, 73.

BeATtY, R. A. (1972) The genetics of size and shape of spermatozoan organelles. In: Proc. int. Symp. on The Genetics of the Spermatozoon, Edinburgh, August 1971, p. 97. Eds. and Publishers: R. A. Beatty and S. Gluecksohn-Waelsch, Department of Genetics, University of Edinburgh, and Department of Genetics, Albert Einstein Gollege of Medicine, New York. Edinburgh and New York.

Beatty, R. A. \& Mukherjee, D. P. (1963) Spermatozoan characteristics in mice of different ages. $\mathcal{F}$. Reprod. Fert. 6, 261.

Beattr, R. A. \& Sharma, K. N. (1960) Genetics of gametes. III. Strain differences in spermatozoa from eight inbred strains of mice. Proc. R. Soc. Edinb. B, 68, 25.

Bowman, P. \& McLaren, A. (1970) Viability and growth of mouse embryos after in vitro culture and fusion. 7. Embryol. exp. Morph. 23, 693.

HANCOCK, J. L. (1951) A staining technique for the study of temperature shock in semen. Nature, Lond. $167,323$.

IlLISson, L. (1969) Spermatozoal head shape in two inbred strains of mice and their $F_{1}$ and $F_{2}$ progenies. Aust. F. biol. Sci. 22, 947.

McLaren, A. \& Michie, D. (1956) Studies on the transfer of fertilized mouse eggs to uterine fostermothers. I. Factors affecting the implantation and survival of native and transferred eggs. $\mathcal{F}$. exp. Biol. 33, 394.

Pant, K. P. (1972) Patterns of inheritance in the midpiece length of mouse spermatozoa. In: Proc. int. Symp. on the Genetics of The Spermatozoon, Edinburgh, August 1971, p. 116. Eds. and Publishers: R. A. Beatty and S. Gluecksohn-Waelsch, Department of Genetics, University of Edinburgh, and Department of Genetics, Albert Einstein College of Medicine, New York. Edinburgh and New York.

Sharma, K. N. (1960) Genetics of gametes. IV. The phenotype of mouse spermatozoa in four inbred strains and their $\mathrm{F}_{1}$ crosses. Proc. R. Soc. Edinb. B, 68, 54.

Woolley, D. M. \& BEATTY, R. A. (1967) Inheritance of midpiece length in mouse spermatozoa. Nature, Lond. 215, 94. 